\author{
Антонюк П.О. \\ кандидат економічних наук, науковий співробітник \\ відділ ринкових механізмів і структур \\ Інститут проблем ринку та економіко-екологічних \\ досліджень НАН України \\ Французький бульвар, 29, м. Одеса, Україна, 65044 \\ E-mail:paul_antonyuk@ukr.net \\ ORCID ID: 0000-0002-8100-2563 \\ Ступницька Т.M. \\ кандидат економічних наук, доцент \\ кафедра обліку та аудиту \\ E-mail: t.stupnitska@gmail.com \\ ORCID ID: 0000-0002-2517-2795
}

\author{
Антонюк О.П. \\ кандидат економічних наук, доцент \\ кафедра обліку та аудиту \\ E-mail: olegantoni@ukr.net \\ ORCID ID: 0000-0002-9182-4982
}

\author{
Баранюк X.O. \\ асистент \\ кафедра обліку та аудиту \\ Одеська національна академія харчових \\ технологій \\ вул. Канатна, 112, м. Одеса, Україна, 65039 \\ E-mail: baranyuk.kristina@gmail.com \\ ORCID ID: 0000-0002-3346-0332
}

\title{
АНАЛІЗ СТАНУ ТОРГІВЛІ АГРОПРОДОВОЛЬЧИМИ ТОВАРАМИ УКРАЇНИ 3 КРАЇНАМИ АФРИКИ
}

Дана стаття присвячена дослідженню сучасного стану торгівлі України і країн Африки агропродовольчими товарами. 3 цією метою пропонується використання в аналізі товарної та територіальної (по субрегіонах Афррики) структур експорту, що дає можливість встановити особливості напрямів експортних потоків. Виявлено, що основні обсяги агропродовольчої продукції направляються в шість країн Північної Афррики. В інші 48 країн, а саме в Субсахарську Африку, де проживає більше 80,0\% населення континенту, що є потенційно величезним ринком для українських підприємств, приходиться близько 18,0\% імпорту з України. Торгівля з цими країнами знаходиться на початковому етапі розвитку. Встановлено, що для всіх субрегіонів, основними товарами імпорту з України $є$ продукти рослинного походження і жири та олії тваринного та рослинного походження. Але їх частка в загальному продовольчому імпорті поступово скорочується з 96,4\% в 2013 р. до 84,3\% в 2017 р. Також аналіз експорту в розрізі товарних груп показує чітку тенденцію до зростання абсолютно і відносно продажу з України продуктів тваринного походження і готових харчових продуктів. Виконаний аналіз показує, що Україна недостатньо використовує можливості розширення своєї присутності на африканському ринку агропродовольчої продукції. Зроблено висновки про високу ефективність торгівлі з країнами Африки, про що свідчить коефіцієнт покриття експортом імпорту - самий високий у порівнянні з іншими напрямами - СНД, ЕС, Азії. Доведено необхідність для розширення експорту в Африку різних заходів державної підтримки, в т.ч. дипломатичної. У висновках представлено рекомендації стосовно збільшення продаж агропродовольчої продукції на ринках країн Африки, а також напрям подальших наукових досліджень.

Ключові слова: агропродовольча продукція, експорт, товарна структура, субрегіони, територіальна структура, сальдо, дипломатична підтримка.

This work is licensed under a Creative Commons Attribution 4.0 International License http://creativecommons.org/licenses/by/4.0/

Постановка проблеми та її зв'язок з важливими науковими та практичними завданнями. Починаючи 32014 р. агропродовольча продукція стає головним експортним товаром України. Це один 3 небагатьох видів товарів, експорт яких зріс за період 2013-2017 рр. на 104,9\% при тому, що весь експорт товарів скоротився на $30,6 \%$. Зростання агропродовольчого експорту має виключно важливе значення для економіки держави, іiі фінансового становища, так як саме по цій групі товарів формується значне позитивне сальдо. Проте з суттєвою втратою позицій на рин- ках країн СНД, яке може тривати і в найближчі роки, iз збільшенням експортних можливостей держави, постає проблема розширення експорту агропродовольчої продукції в інші об'єднання та країни світу. Саме тому дослідження питань агропродовольчого експорту з України до найбільших ії імпортерів набуває особливої актуальності.

Аналіз останніх публікацій по проблемі. Агропродовольча продукція поступово становиться важливим експортним товаром, що потребує постійного аналізу можливості розширення іiі продаж на 
зовнішніх ринках. Різні аспекти зовнішньої торгівлі агропродовольчими товарами висвітлюються в роботах таких вітчизняних вчених-економістів, як: Б.В. Духницький [4], І.Г. Кириленко [5], М.А. Лисак, О.О. Шеремет [6], В.М. Нелеп [8], Ю.О. Лупенко [9]. Проте проблема збільшення експорту вітчизняної продукції сільського господарства і харчової промисловості потребує постійного аналізу рівня, динаміки і структури українського експорту в напряму основних країн-імпортерів.

Формулювання цілей дослідження. Метою даного дослідження є аналіз динаміки обсягів, товарної та територіальної структури, тенденцій і результативності експорту агропродовольчої продукції в країни Африки, особливостей їх ринку та оцінка перспектив зростання вітчизняного експорту.

Виклад основних результатів та їх обгрунтування. В умовах інтеграції України в світову економічну систему важливе місце займає торгівля. В останні роки головним експортним товаром України стає продукція сільського господарства та харчової промисловості (товарні групи 1-24 УКТЗЕД), частка якої в загальному експорті товарів зросла з 27,2\% в 2013 р. до 41,0\% в 2017 р. [1]. Ці зміни відбулися за умов скорочення загального експорту товарів з України з 62,3 млрд. дол. в 2013 р. до 43,3 млрд. дол. 2017 p., або на 30,6 \% і зростання експорту агропродовольчої продукції, відповідно, з 16,93 млрд. дол. до 17,76 млрд. дол. або на 104,9\%. Україна зміцнює свої позиції на світовому аграрному ринку - входить до десятки найбільших світових виробників зерна і олійного насіння та займає лідируючі позиції серед експортерів цієї продукції. За прогнозами до 2030 р. виробництво зерна в Україні сягатиме 80 млн. т., а експортний фонд перевищить 50 млн.т. [7]. Зростання експортних можливостей в умовах різких змін в географічній структурі експорту, головною ознакою яких було скорочення торгівлі з країнами СНД, ставить питання розширення ринків збуту, одним з яких є ринок країн Африки. Цей континент - один $з$ регіонів світу, що швидко розвивається, але недостатньо насичений товарами.

Однією $з$ найбільш актуальних проблем для Африки являється саме забезпечення продовольчими товарами, потреба в яких існувала завжди, а нині загострюється як результат швидкого зростання чисельності населення і платоспроможного попиту. При недостатньому внутрішньому виробництві продуктів харчування в країнах континенту продовольча проблема вирішується за рахунок імпорту, масштаби якого досить значні. В 2016 р. африканський континент витратив 65,8 млрд. дол. на імпорт продуктів харчування, а основними експортерами являються Бразилія, Франція, Індія і США [16]. В умовах Африки усі основні продукти харчування $є$ предметом чистого імпорту і ситуація в цьому плані лише посилюється, особливо стосовно продуктів $з$ високою доданою вартістю. По даним ФАО до 2023 р. дефіцит продуктів харчування для країн континенту може скласти, тис. тон: пшениця - 44987; інші зернові 22851; олійні культури - 3494; борошно - 4461; масло вершкове -161 ; рослинні олії - 8775 ; цукор -11684 [18].

Україна розширює експорт агропродовольчої продукції в цей перспективний регіон і динаміка в цьому напрямку досить висока - з 1996 р. по 2017 р. обсяг експорту зріс майже в 24 рази. Нині країни Африки в експорті продуктів харчування з України займають третє місце після країн СС та Азії. В результаті скорочення всього товарного експорту до країн Африки з 5095 млн. дол. в 2013 р. до 4048 млн. дол. в 2017 р. або на 21,6\% і зростанні експорту агропродовольчої продукції, ця продукція стає головним експортним товаром з України з часткою в 2017 р. 62,9\%, що перевищує цей показник по іншим регіонах світу.

Африку не слід розглядати як один великий одноманітний ринок, так як всі країни цього континенту відрізняються між собою рівнем розвитку, національними особливостями населення, наявності об'єктів інфраструктури тощо, що впливає на обсяг і структуру експорту (табл. 1).

Таблиця1

Структура експорту в розрізі субрегіонів Африки*

\begin{tabular}{|c|c|c|c|c|c|c|c|c|}
\hline \multirow{2}{*}{ Субрегіони } & \multirow{2}{*}{$\begin{array}{l}\text { Кількість } \\
\text { країн }\end{array}$} & \multicolumn{2}{|c|}{$\begin{array}{c}\text { Населення станом } \\
\text { на } 2016 \text { p. }\end{array}$} & \multicolumn{2}{|c|}{2015 p. } & \multicolumn{2}{|c|}{$2017 \mathrm{p}$} & \multirow{2}{*}{$\begin{array}{l}2017 \text { р. в \% до } \\
2015 \text { р. }\end{array}$} \\
\hline & & млн. осіб & $\%$ & млн. дол. & $\%$ & млн. дол. & $\%$ & \\
\hline $\begin{array}{l}\text { Північна } \\
\text { Африка }\end{array}$ & 6 & 224 & 18,7 & 1754,8 & 87,6 & 2098,9 & 85,5 & 119,6 \\
\hline $\begin{array}{l}\text { Східна } \\
\text { Африка }\end{array}$ & 18 & 393 & 32,8 & 138,6 & 6,9 & 141,4 & 5,4 & 102,0 \\
\hline $\begin{array}{l}\text { Центральна } \\
\text { Африка }\end{array}$ & 9 & 166 & 13,8 & 9,9 & 0,5 & 40,6 & 1,6 & 4,1 рази \\
\hline $\begin{array}{l}\text { Західна } \\
\text { Африка }\end{array}$ & 16 & 353 & 29,5 & 40,9 & 2,1 & 198,7 & 7,8 & 4,8 рази \\
\hline $\begin{array}{l}\text { Південна } \\
\text { Африка }\end{array}$ & 5 & 62 & 5,2 & 58,8 & 2,9 & 67,2 & 2,7 & 114,3 \\
\hline Всього & 54 & 1198 & 100,0 & 2003,0 & 100,0 & 2546,8 & 100,0 & 127,1 \\
\hline
\end{tabular}

*розраховано авторами за даними Державної служби статистики України [2] 
Як видно з даних табл. 1, особливості африканського ринку з точки зору експорту агропродовольчих товарів з України, проглядаються в територіальній структурі - по субрегіонах континенту. Найбільші експортні потоки агропродовольчої продукції направляються в країни Північної Африки - Алжир, Сгипет, Лівію, Марокко, Судан, Туніс, що входять в десятку найбільших імпортерів з України. Лідером в імпорті з України являється Єгипет з часткою близько 50\% всього імпорту континенту. Але в продовж 2013-2017 рр. експорт до Сгипту скоротився 31524 млн. дол. до 1259 млн. дол., що значно зменшило результати та динаміку всього континенту. Інші регіони Африки, де проживає 81,3\% населення 48 країн, імпортують лише 15-17\% продукції з України. В числі десяти найбільших імпортерів, по даних 2017 р., ці регіони представлені лише чотирма країнами: Кенія (Східна Африка), Мавританія, Нігерія (Західна Африка) та ПАР (Південна Африка). Саме ці регіони, тобто Африка на південь від Сахари (Субсахарська Африка), можна розглядати як досить перспективні для нарощування українського експорту.
В імпорті агропродовольчих товарів країнами Африки по окремим регіонам спостерігаються певні відмінності, проте загальною рисою являється підвищений попит на пшеницю, кукурудзу, рослинні олії, цукор [20]. Крім цього в значних обсягах імпортуються овочі і фрукти, м'ясо, риба, молочні продукти та інші. Це виглядає нелогічним враховуючи, що на континент приходиться $65 \%$ орних земель світу. Якщо ситуація 3 малоефективним використанням сільськогосподарського потенціалу континенту істотно не зміниться, то до 2030 р. імпорт продовольства в країни Африки перевищить 110 млрд. дол. [19].

У товарній структурі експорту агропродовольчих товарів 3 України найбільшу частку мають продукти рослинного походження (головним чином кукурудза, пшениця, ріпак, соєві боби), та жири і олії тваринного або рослинного походження (в основному олія соняшникова нерафінована). Саме ці види товарів найбільше потребують імпортери країн Африки, що підтверджує товарна структура агропродовольчого експорту з України до споживачів континенту (табл. 2).

Таблиця 2

Товарна структура експорту агропродовольчої продукції до країн Африки *

\begin{tabular}{|l|c|c|c|c|c|c|c|c|}
\hline \multirow{2}{*}{$\begin{array}{c}\text { Розділи продукції } \\
\text { відповідно УКТЗЕД }\end{array}$} & \multicolumn{2}{|c|}{2013 p. } & \multicolumn{2}{|c|}{2015 p. } & \multicolumn{2}{|c|}{2017 p. } & \multicolumn{2}{|c|}{$\begin{array}{c}2017 \text { р. до } 2013 \\
\text { p. }\end{array}$} \\
\cline { 2 - 9 } & млн. дол. & $\%$ & млн. дол. & $\%$ & млн. дол. & $\%$ & абс. & $\% /+/-$ \\
\hline $\begin{array}{l}\text { 1. Живі тварини, продукти тва- } \\
\text { ринного походження }\end{array}$ & 30 & 1,2 & 68 & 3,4 & 160 & 6,3 & 130 & 5,3 рази \\
\hline $\begin{array}{l}\text { 2. Продукти рослинного похо- } \\
\text { дження }\end{array}$ & 1965 & 77,4 & 1559 & 77,8 & 1934 & 75,9 & -31 & 98,4 \\
\hline $\begin{array}{l}\text { 3. Жири та олії тваринного та } \\
\text { рослинного походження }\end{array}$ & 482 & 19,0 & 239 & 11,9 & 215 & 8,4 & -267 & 44,6 \\
\hline 4. Готові харчові продукти & 62 & 2,4 & 137 & 6,9 & 238 & 9,4 & 176 & 3,8 рази \\
\hline Всього & 2539 & 100,0 & 2003 & 100,0 & 2547 & 100,0 & 8 & 100,3 \\
\hline
\end{tabular}

* розраховано авторами за даними Державної служби статистики України [2]

Як видно, до країн Африки Україна найбільше експортує продукти рослинного походження та жири і олії тваринного та рослинного походження. Правда їх частка скорочується як абсолютно, так i відносно. Натомість зростає експорт продукції тваринного походження і готових харчових продуктів, як за рахунок розширення номенклатури, так збільшення обсягів продаж.

Особливості ринку африканських країн стають примітними при розгляді товарної структури агропродовольчого експорту по субрегіонах континенту. (табл. 3 ).

Таблиця 3

Товарна структура експорту агропродовольчої продукції з України в розрізі субрегіонів Африки*

\begin{tabular}{|l|c|c|c|c|c|c|}
\hline \multicolumn{1}{|c|}{ Субрегіони } & Рік & $\begin{array}{c}\text { Живі тварини і } \\
\text { продукти тва- } \\
\text { ринного похо- } \\
\text { дження }\end{array}$ & $\begin{array}{c}\text { Продукти } \\
\text { рослинного } \\
\text { походження }\end{array}$ & $\begin{array}{c}\text { Жири та олії } \\
\text { тваринного та } \\
\text { рослинного } \\
\text { походження }\end{array}$ & $\begin{array}{c}\text { Готові харчові } \\
\text { продукти }\end{array}$ & Всього \\
\hline $\begin{array}{l}\text { Північна } \\
\text { Африка }\end{array}$ & 2013 & 0,6 & 75,2 & 21,5 & 2,7 & 100,0 \\
\hline \multirow{2}{*}{$\begin{array}{l}\text { Східна } \\
\text { Африка }\end{array}$} & 2017 & 5,9 & 77,0 & 8,9 & 8,2 & 100,0 \\
\hline \multirow{2}{*}{$\begin{array}{l}\text { Центральна } \\
\text { Африка }\end{array}$} & 2013 & 0,5 & 94,4 & 5,1 & - & 100,0 \\
\cline { 2 - 7 } & 2013 & 2,8 & 80,7 & 8,6 & 7,9 & 100,0 \\
\hline
\end{tabular}




\begin{tabular}{|l|c|c|c|c|c|c|}
\hline \multirow{2}{*}{ Субрегіони } & Рік & $\begin{array}{c}\text { Живі тварини і } \\
\text { продукти тва- } \\
\text { ринного похо- } \\
\text { дження }\end{array}$ & $\begin{array}{c}\text { Продукти } \\
\text { рослинного } \\
\text { походження }\end{array}$ & $\begin{array}{c}\text { Жири та олії } \\
\text { тваринного та } \\
\text { рослинного } \\
\text { походження }\end{array}$ & $\begin{array}{c}\text { Готові харчові } \\
\text { продукти }\end{array}$ & Всього \\
\hline $\begin{array}{l}\text { Західна } \\
\text { Африка }\end{array}$ & 2013 & 42,9 & 38,2 & 1,0 & 17,9 & 100,0 \\
\cline { 2 - 7 } & 2017 & 9,3 & 58,6 & 6,4 & 25,7 & 100,0 \\
\hline Південна & 2013 & 0,3 & 92,8 & 6,7 & 0,2 & 100,0 \\
\cline { 2 - 7 } \\
Африка & 2017 & 5,2 & 90,0 & 1,3 & 3,5 & 100,0 \\
\hline
\end{tabular}

* розраховано авторами за даними Державної служби статистики України [2]

Дані про товарну структуру за 2013 і 2017p. показують, що для країн усіх субрегіонів головним продуктом імпорту з України є продукти рослинного походження. А найбільша частка цих продуктів в імпорті країн характерна для Східної та Південної Африки. Країни на південь від Сахари імпортують відносно менше жирів та олії тваринного та рослинного походження. Натомість в країнах Центральної Африки значну частку в імпорті складають продукти тваринного походження, а в країнах Західної Африки, як продукти тваринного походження, так і готові харчові продукти.

Товари з України цілком конкурентні на африканському ринку на якому відсутні обмеження, що існують на інших ринках, насамперед СС. В багатьох випадках Україна ще має відкривати для себе ринки країн Африки, тому не слід вважати, що українська продукція представлена на африканському ринку в задовільному для свого потенціалу обсягах. Так країни континенту являються значними імпортерами м'яса, особливо м'ясо птиці, де основними поставщиками виступає Бразилія та країни Європейського Союзу. За період 2013-2017 p.p. Україна суттєво наростила експорт м'яса птиці та інших продуктів тваринного походження до країн Африки. В 2017 р. до країн Африки було експортовано 66898 т. м'яса та субпродуктів свійської птиці (основна продукція товарної групи 02 «М'ясо та їстівні субпродукти») проти 10995 т. в 2013p., тобто більш ніж у 6 разів. Завдяки високим темпам росту частка країн Африки з загальному експорті м'яса птиці з України зросла з 7,5\% в 2013 р. до 24,6\% в 2017 р. Розширюється, як і по інших товарах, географія поставок м'яса птиці. Основні покупці, що систематично нарощують закупки це: Північна Африка - Єгипет, Лівія; Західна Африка Гамбія, Гвінея Мавританія; Центральна Африка Габон, Демократична Республіка Конго.
Споживання молока і молочних продуктів в країнах континенту в значній мірі забезпечується за рахунок імпорту, масштаби якого досить значні. Тільки країни на південь від Сахари імпортують молочних продуктів на суму 2,4 млрд. дол. [14]. Але цей напрям експорту не дуже популярний у наших підприємств. В 2017 р. в країни на південь від Сахари було експортовано продукції: товарної групи 04 «Молоко та молочні продукти, яйця птиці, натуральний мед» лише на суму 14,6 млн. дол., а в країни Північної Африки на суму 48,6 млн. дол. В основному експортували два виду продукції: молоко і вершки згущені та 3 додаванням цукру і масло вершкове. Успішно розвивається експорт саме масла вершкового. Розпочавши його експорт у 2015 р. 3 обсягу 4053 т. в 2017 р. було реалізовано 8745 т. на суму 37,7 млн. дол. В продовж цього короткого періоду єдиними імпортерами були Марокко і Сгипет. Масштаби українського експорту молочних продуктів виглядають досить скромно у порівнянні $з$ потребами імпортерів в т.ч. африканських, що пояснюється обсягами виробництва молока в Україні. В 2017 р. виробництво молока в Україні склало лише 47,9\% від рівня 1990 р. Зрозуміло, що без істотного зростання виробництва молока неможливо не тільки наситити внутрішній ринок, але й формувати необхідні ресурси для експорту молока та молочних продуктів.

Нині країни Африки являються одними 3 найбільших імпортерів зернових, при цьому Єгипет, Алжир, Марокко і Туніс є одними з найбільших у світі імпортерів пшениці [15], що відкриває перед експортерами з України великі можливості для освоєння такого ринку. В торгівлі України з країнами Африки переважають саме зернові культури - пшениця, ячмінь, кукурудза, а також соєві боби (табл. 4).

Експорт зернових культур і соєвих бобів в країни Африки*

\begin{tabular}{|c|c|c|c|c|c|c|}
\hline \multirow{2}{*}{ Культури } & \multicolumn{2}{|c|}{$2013 \mathrm{p}}$. & \multicolumn{2}{|c|}{2017 p. } & \multicolumn{2}{|c|}{2017 р. в \% до 2013 р. } \\
\hline & тис. т. & млн. дол. & тис. т. & млн. дол. & тис. т. & мЛн. дол. \\
\hline 1. Пшениця & 4146 & 1026,1 & 5723 & 933,7 & 138,0 & 91,0 \\
\hline 2. Ячмінь & 352 & 87,5 & 673 & 100,4 & 191,2 & 114,7 \\
\hline 3. Кукурудза & 3075 & 702,8 & 4365 & 667,7 & 141,9 & 95,0 \\
\hline 4. Соя & 243 & 120,8 & 425 & 154,2 & 174,9 & 127,6 \\
\hline Всього & 7816 & 1937,2 & 11186 & 1856,0 & 143,1 & 95,8 \\
\hline
\end{tabular}

* розраховано авторами за даними Державної служби статистики України [2] 
Розглянуті дані свідчать, що чотири культури складають основу вітчизняного експорту до країн Африки. На них приходиться більше 96\% експорту продукції рослинного походження і близькі 73-76\% загального експорту в цьому напряму. Період 20132017 рр. характеризується значним зниженням експортних цін, (\%): пшениця - 34,6; ячмінь - 39,9; кукурудза - 32,9; соєві боби - 26,9, в результаті чого фінансові результати суттєво зменшились. При зростанні фізичного обсягу експорту на $143,1 \%$ валютна виручка скоротилась на 4,2\%. Основні потоки розглянутих культур направляються в країни Північної Африки - пшениці - 78\%, ячменю - 98,6\%, кукурудзи - 88,8\%, соєвих бобів - 100\% (за даними 2017 р.). Значні обсяги зернових імпортують країни на південь від Сахари: Кенія, Мавританія, Південна Африка, Нігерія, Сенегал.

Країни Африки є перспективним ринком для продукції переробки зернових. В першу чергу мова іде про борошно пшеничне. Експорт борошна пшеничного зріс за період 2013 - 2017 pр. 36005 т. до 97293 т., а частка країн Африки в загальному експорті цієї продукції досягла 22,0\%. Вітчизняним експортерам борошна слід бути готовими до надзвичайної конкуренції з боку борошномелів Туреччини, що $є$ найбільшим у світі експортером цієї продукції і тому, що ряд країн Африки , які активно купують нашу продукцію, виявляються не найблагонадійнішими [3]. В основному борошно пшеничне іде в ті країни, що мало імпортують пшеницю - Ангола, Бенін, Гана, Сомалі, Сьєра-Леоне та інші. Найбільшим імпортером борошна пшеничного являється Ангола,яка в 2017 р. імпортувала 3 України 39,7 тис.т. продукції, або $40,8 \%$ обсягу континенту. Як відомо Ангола за рік імпортує борошна більше, чим весь річний український експорт [12]. Маючи значні ресурси пшениці та виробничі потужності борошномельних підприємств Україна може значно наростити виробництво борошна і збільшити його експорт, в тому числі і до країн Африки.

В останні роки Україна в певній мірі втрачає свої позиції на африканському ринку соняшникової олії. Експорт в країни Африки скоротився 3 480,5 тис.т. в 2013 р. до 264,1 тис.т. в 2017 р. або на 45\% головним чином за рахунок скорочення поставок до Єгипту, як головного імпортера на континенті. Єгипет в цей період скоротив імпорт олії на 232 тис.т., причинами чого можуть бути зростання внутрішнього виробництва соняшникової олії, збільшення виробництва соєвої олії (тільки з України імпорт соєвих бобів зріс на 170 тис.т.), а також збільшення закупівель олії з Росії по ціні, що більше влаштовувала імпортерів [10]. Проте ряд країн збільшили закупівлі цієї продукції, в т.ч. Судан, Марокко, Ангола, Гана, Ефіопія, Кот-Д'Івуар, Лівія, Сенегал, Туніс. Перспектива зростання експорту соняшникової, соєвої та ріпакової олії пов'язується з освоєння ринків Субсахарської Африки і в першу чергу таких густонаселених (з населенням кожної більш як 55 млн. мешканців), як Нігерія, Ефіопія, Демократична Республіка Конго, Південно-Африканська республіка, Танзанія.
Перспективним сегментом українського агропродовольчого експорту в країнах Африки являються готові харчові продукти. Проте основою цих товарів $\epsilon$ не продукти харчування (товарні групи 1622), а залишки і відходи харчової промисловості, та тютюн, і промислові замінники тютюну, відповідно товарні групи 23 та 24. Їх частка в готових харчових продуктах скоротилась з 93,7\% в 2013 р. до 50,9\% в 2017 р., незважаючи на абсолютне зростання експортної виручки за ці товари відповідно з 57 млн. дол. до 121 млн. дол. Експорт цих товарів направляється практично в п’ять держав Північної Африки - Алжир, Єгипет, Лівія, Марокко і Туніс. Головним імпортером продукції товарної групи 23 виступає Марокко (в 2017 р. - 46 млн. дол. або 69,7\% усього африканського імпорту), а продукція товарної групи 24 практично повністю іде в Єгипет (в 2017 р. 54,6 млн. дол. або 98,7\% експорту в країни Африки). Більш динамічно розвивається саме експорт залишків і відходів харчової промисловості, особливо макухи соняшникової. Якщо в 2013p. країни північної Африки імпортували 213,3 тис.т. відходів (в т.ч. 150,1 тис.т. макухи соняшникової), то в 2017 р. обсяг імпорту зріс до 382,0 тис.т.(в т.ч. 356,7 тис.т. макухи соняшникової). Зниження експортних цін в 2013-2017 р.p. негативно вплинуло на виручку від експорту. При зростанні експорту в фізичному обсязі на 179,3\% експортна виручка зросла з 54,4 млн. дол. в 2013 р. до 65,9 млн. дол. в 2017 р. або на 121,1\%.

Приріст експорту готових харчових продуктів за період 2013-2017 рр. в більшій мірі мав місце за рахунок зростання продуктів харчування - 3 4,5 млн. дол. в 2013p. до 117 млн. дол. в 2017 р. Експорт зростав по продукції усіх товарних груп 16-22, але в найбільший мірі по продукції товарної групи 17 «Цукор і кондвироби 3 цукру», саме за рахунок цукру. Якщо в 2013 р. із країн континенту тільки Бенін закупив 840 т. цукру на суму 398 тис. дол., то вже в 2017 р. поставки до 14 країн континенту склали 1945337 т. на суму 92782 тис. дол. Ринок цукру африканських країн дає можливість для країн експортерів, в. т.ч. й Україні, збільшувати продажі продукції з огляду на те, що більше половини обсягу споживання цукру населенням Африки покривається за рахунок імпорту, що постійно зростає. В 2017 р. обсяг імпорту склав 13,7 млн.т., з яких білий цукор - 6,4 млн.т. і жовтий цукор - 7,3 млн.т. [17]. Україна тільки з 2016р. розпочала інтенсивно освоювати ринок білого цукру, та їі частка в загальному імпорті цієї продукції поки не перевищує три відсотки. Основні поставки білого цукру здійснюються в країни на південь від Сахари: Гвінея, Кот-Д'Івуар, Мавританія, Сомалі, Того та ін., де відсутні потужності по рафінації цукру-сирцю.

Продукти харчування (товари групи 16, 1822) найменш представлені на африканському ринку. Їх експорт з України хоча і зріс 3 4,0 млн. дол. в 2013 p. до 17,5 млн. дол. в 2017 р., проте в загальному експорті до континенту їх частка незначна. Головним чином «Продукти переробки овочів» направляються в Єгипет, «Різні харчові продукти» - в Сгипет та Нігерію, «Алкогольні і безалкогольні напої, оцет» - 
в Алжир. Такі результати поясняються, як станом вітчизняного виробництва продуктів харчування, так і певною пасивністю вітчизняних експортерів на невідомому африканському ринку [13].

Розширення експорту до країн Африки пов'язується 3 рівнем дипломатичних відносин між Україною та країнами континенту. На сьогодні наша держава підтримує дипломатичні відносини на рівні Посольств 311 країнами Африки, при 54 існуючих там державах. Це п'ять країн Північної Африки (Алжир, Сгипет, Лівія, Марокко, Туніс) та шість країн Субсахарської Африки (Ангола, Ефіопія, Кенія, Нігерія, ПАР, Сенегал). Всі ці країни - це потужні імпортери агропродовольчої продукції, в т.ч. і з України. В 2017 р. український експорт в ці країни склав 2278 млн. дол., або 89,5\% обсягу континенту. Роль посольств в налагодженні торговельних зв'язків між партнерами в Україні та Африки надзвичайно велика. Проте до цього часу Україна не має дипломатичних зв'язків такого рівня з рядом африканських країн (з чисельністю населення більш як 20 млн. мешканців) в т.ч., Мозамбік, Танзанія, Уганда, Демократична республіка Конго, Гана, Мадагаскар, Ангола, Камерун, Кот-Д'Івуар. В 2017 р. їх загальний агропродовольчий імпорт з України склав лише 70,3 млн. дол., або 2,8\%. Необхідно зауважити, що в Україні немає чіткої стратегії у відношеннях з Африкою і ситуація ускладняється через нехватку українських дипломатів в регіоні. Більш того, питання економічного співробітництва України і країн Африки залишаються поза увагою керівників нашої держави. За роки незалежності жоден президент чи прем'єр-міністр України не поїхали налагоджувати економічні зв'язки з Африкою [11].

Товарний експорт до країн Африки, в т.ч. і агропродовольчий, є важливим не тільки $з$ точки зору отримання валютної виручки але й значного позитивного сальдо (табл. 5).

Таблиця 5

Баланс зовнішньої торгівлі України агропродовольчими товарами*

\begin{tabular}{|c|c|c|c|c|c|c|c|c|}
\hline \multirow{2}{*}{ Напрями експорту } & \multicolumn{3}{|c|}{2013 р. (млн. дол.) } & \multirow{2}{*}{$\mathrm{K}_{\mathrm{n}}$} & \multicolumn{3}{|c|}{2017 р. (млн. дол.) } & \multirow[b]{2}{*}{$\mathrm{K}_{\mathrm{n}}$} \\
\hline & Експ. & Імп. & Сальдо & & Експ. & Імп. & Сальдо & \\
\hline СНД & 3611 & 1058 & 2553 & 3,4 & 1353 & 138 & 1215 & 9,8 \\
\hline$\epsilon \mathrm{C}$ & 4485 & 3115 & 1370 & 1,4 & 5617 & 2011 & 3606 & 2,8 \\
\hline Азія & 6191 & 1615 & 4576 & 3,8 & 7880 & 959 & 6921 & 8,2 \\
\hline Африка & 2539 & 377 & 2162 & 6,7 & 2547 & 220 & 2327 & 11,5 \\
\hline Інші & 104 & 1847 & -1770 & 0,1 & 361 & 971 & -610 & 0,4 \\
\hline Всього & 16930 & 8039 & 8891 & 2,1 & 17758 & 4299 & 13459 & 4,1 \\
\hline
\end{tabular}

Україна відносно мало імпортує агропродовольчих товарів з Африки. В основному це продукція чотирьох товарних груп: «Їстівні плоди та горіхи» (Єгипет, Південна Африка), «Кава, чай» (Ефіопія, Кенія, Уганда), «Какао та продукти 3 нього» (Гана, Кот-Д'Івуар), «Тютюн і промислові замінники тютюну» (Зімбабве, Малаві, Мозамбік, Танзанія), на які приходиться по даним 2017 р. більш як 87\% агропродовольчого імпорту з Африки. Слід відзначити, що всі основні експортери до України, за виключенням Єгипту, це країни Субсахарської Африки. Невеликий обсяг агропродовольчого імпорту 3 Африки, який до того ж в останні роки суттєво скоротився, забезпечує значне позитивне сальдо і самий високий коефіцієнт покриття експортом імпорту.

Висновки та перспективи подальших досліджень. Країни Африки на сьогодні і в перспективі являються одними 3 головних світових імпортерів агропродовольчої продукції, що відкриває перед країнами-експортерами, в т.ч. й Україні, великі можливості для нарощування експорту. В останні роки в українському експорті продукції сільського господарства та харчової промисловості цей континент займає третє місце після країн ЄС та Азії. Проте в африканському агропродовольчому імпорті по матеріалах 2016 р., частка України складає лише 3,3\%, що значно менше у порівнянні з іншими країнами. В ході дослідження експорт розглядається з точки зору як товарної структури, так і територіальної структури по субрегіонах Африки, що дає можливість більш детально оцінити регіональні особливості ринку. В імпорті агропродовольчих товарів країнами Африки переважають пшениця, кукурудза, олійні культури, борошно, рослинні олії, що являються для України основними товарами іiі експорту, в тому числі і до африканських країн. Така аналогія в номенклатурі товарів африканського імпорту і експорту з України пояснює сучасну товарну структуру продажу української агропродовольчої продукції в країни Африки і означає хороші перспективи до їх значного збільшення в майбутньому, виходячи з можливостей України, особливо, стосовно виробництва і експорту зернових.

В товарній структурі експорту з України до країн Африки найбільшу частку складають продукти рослинного походження (в основному кукурудза, пшениця, ріпак, соєві боби) та жири і олії тваринного або рослинного походження (в основному олія соняшникова нерафінована), та в перспективі ці товари будуть основою українського експорту до країн континенту.

Територіальна структура експорту з України по субрегіонах Африки свідчить про те, що основні потоки агропродовольчої продукції направляються в шість країн Північної Африки. Натомість в 48 країн 
Субсахарської Африки, де проживає більш як 80\% населення континенту приходиться лише близько 18,0 \% по даним 2017 р. українського експорту. При цьому кожен субрегіон має свої особливості стосовно товарної структури імпорту з України.

В 2013-2017 pр. в товарній структурі українського експорту до країн Африки відбулися значні зміни - частка живих тварин і продукції тваринного походження та готових харчових продуктів зросла 3 3,6\% в 2013 р. до 15,7\% в 2017 р., а сума експорту відповідно, з 92 млн. дол. до 398 млн. дол., або в 4,3 рази.

У порівнянні з іншими торговими партнерами Україна відносно мало імпортує продукції сільського господарства і харчової промисловості з Африки, в результаті чого коефіцієнт покриття імпорту експортом перевищує аналогічний показник в торгівлі з країнами СНД, СС та Азії.

Виконаний аналіз товарної та територіальної структур експорту з України до Африки агропродовольчої продукції свідчить про наявність значних можливостей для збільшення продаж цієї продукції на ринках країн континенту:

1. Експорт продукції тваринного походження може зростати за умов випереджаючого роз- витку тваринних галузей, посилення конкурентоспроможності продукції товарних груп 02 «'ясо та їстівні субпродукти» і 04 «Молоко та молочні продукти, яйця птиці, натуральний мед». В основному це стосується таких видів продукції, як м'ясо птиці, молоко і вершки згущені та 3 добавленням цукру, масло вершкове.

2. Збільшення експорту продукції переробки зерна (в першу чергу борошна пшеничного) можливе лише при зростанні вітчизняного виробництва до рівня країн-конкурентів на світовому ринку.

3. 3 готових харчових продуктів найбільш можливим зростання експорту стосується таких видів, як цукор, макуха, одержана під час добування рослинних жирів (соєва, соняшникова, ріпакова), тютюнові вироби.

4. Освоєння ринку країн Субсахарської Африки вимагає розробки і реалізації ефективної стратегії посилення українського бізнесу на основі наявності значних експортних ресурсів, експортерів, здатних працювати в непростих умовах, і серйозної дипломатичної підтримки.

Перспективним напрямом подальших наукових досліджень може бути оцінка особливостей субрегіональних ринків і експортно-імпортних операцій.

\section{Література}

1. Антонюк О.П., Антонюк П.О., Лисюк В.М. Країни Азії - головний партнер України в торгівлі агропродовольчим товарами // Економіка харчової промисловості. 2018. Т. 10, вип. 2. С. 22-30. doi: 10.15673/fie.v10i2957 5.04.2019).

2. Державна служба статистики України: [Веб-сайт]. 2019. URL: http://ukrstat.gov.ua/ (дата звернення:

3. Друженко В. Борошно: шляхи експорту незбагненні // Пропозиція. 2018. вип. 1. С. 158-161.

4. Духницький Б.В. Глобальний попит на продовольство // Економіка АПК. 2018. вип. 8. С. 102-105.

5. Кириленко І.Г., Івченко В.С., Деменчук В.В. Основні тенденції розвитку світового продовольчого ринку та виробництва продовольства в Україні // Економіка АПК. 2018. вип. 9. С. 34-43. doi: 10.32317/22211055.201809034

6. Лисак М.А., Шеремет О.О. Зовнішня торгівлі в умовах інтеграції України // Економіка АПК. 2017. вип. 12. С. 69-74.

7. Маслак О., Куценко І. Особливості українського експорту // Пропозиція. 2017. вип. 10. С. 156-158.

8. Нелеп В.М. Оцінка експортних можливостей агропродовольчого комплексу України // Економіка України. 2011. вип. 9. С. 54-63.

9. Формування глобального і регіонального ринків сільськогосподарської сировини: монографія / за ред. Лупенка Ю.О., Пугачова М.І. Київ: ННЦ "ІАЕ", 2015. 320 с.

10. В новом сезоне Египет существенно сократил импорт украинского подсолнечного масла // ELEVATORIST.COM главный элеваторный сайт страны: [Веб-сайт]. 2018. URL: https://elevatorist.com/novosti/6737-v-novom-sezone-egipet-suschestvenno-sokratil-import-ukrainskogopodsolnechnogo-masla (дата звернення: 2.04.2019).

11. Карта, которая объясняет разницу в торговой политике Запада и Украины // BusinessViews Casual business insights: [Веб-сайт]. 2018. URL: https://businessviews.com.ua/ru/economy/id/karta-kotoraja-objasnjaetraznicu-v-torgovoj-politike-zapada-i-ukrainy-1797/(дата звернення: 2.04.2019).

12. Експорт до Африки: можливості і перешкоди // Пропозиція головна платформа для агробізнесу: [Веб-сайт]. 2017. URL: https://propozitsiya.com/ua/eksport-do-afriki-mozhlivosti-i-pereshkodi (дата звернення: 2.04.2019).

13. Экспорт в Африку: в чем шансы и риски для украинских компаний // ЛіГА.Бізнес: [Веб-сайт]. 2018. URL: https://biz.liga.net/uaexport/all/article/eksport-v-afriku-v-chem-riski-i-vozmojnosti-dlya-ukrainskiykompan (дата звернення: 2.04.2019). 
14. Afrique subsaharienne : la facture des importations alimentaires continue de flamber // LA Afrique TRIBUNE: [Website]. 2017. URL: https://afrique.latribune.fr/finances/commodities/2017-06-11/afrique-subsahariennela-facture-des-importations-alimentaires-continue-de-flamber-736553.html (viewed on: 2.04.2019).

15. L'Egypte, L'Algérie et le Maroc sont le plus gros importateurs du ble dans le monde// Maghreb Emergent: [Website]. 2017. URL: https://maghrebemergent.info/L-Egypte-L-Alg\%C3\% A9rie-et-le-Maroc-sont-le-plus-grosimportateurs-du-ble-dans-le-monde/ (viewed on: 2.04.2019).

16. En 2016, le continent africain a importe des produits alimentaires pour 65.8 milliars dolars (rapport) // ECOFIN: [Website]. 2017. URL: https://www.agenceecofin.com/commerce/2709-50609.-en\%202016-le-continentafricain-a-importe-des-produits-alimentaires-pour-65.8-milliars-dolars-rapport (viewed on: 2.04.2019).

17. En 2017, L`Algerie sepositione sur le marché africain de sucre// Commod Africa: [Website]. 2017. URL: https://www.commodafric.com/08-01-2018-en-2017-lalgerie-sepositione-sur-le- marché-africain-de-sucre (viewed on: 2.04.2019).

18. La situation des marches des produits agricoles. Commerce et securite alimentaire trouver en meilleur equlibre entre les priorites nationale et le lien common // Organisation des Nations unies pour l'alimentation et l'agriculture. 2015. URL: http://www.fao.org/3/a-i5090f.pdf (viewed on: 5.04.2019).

19. Importations alimentaires: L'Afrique attendra 110 milliards dollars d'ici a 2030 jans une alternative credible: Adiac.-congo [Website]. 2017. URL: http://www.adiac.-congo.com/content/importations-alimentaires-L'Afriqueattendra-110-milliards-dollars-d'ici-a-2030-jans-une-alternative-credible (viewed on: 2.04.2019).

20. Les produits les plus importés par l'Afrique: WaystoCup [Website]. 2017. URL:https://www.waystocap.com/blog/?s=Les+produits+les+plus+import\%C3\%A9s+par+1\%27Afrique (viewed on: 2.04.2019).

Стаття надійшла 10.04.2019 Стаття прийнята до друку 24.04.2019 Доступно в мережі Internet 5.07.2019

\author{
Антонюк П.О. \\ кандидат економических наук, научный сотрудник \\ отдел рыночных механизмов и структур \\ Институт проблем рынка и экономико-экологических \\ исследований НАН Украины \\ Французский бульвар, 29, г.Одесса, Украина, 65044 \\ E-mail: paul_antonyuk@ukr.net \\ ORCID ID: 0000-0002-8100-2563
}

Ступницкая Т.M.

кандидат экономических наук, доцент кафедра учета и аудита

E-mail: t.stupnitska@gmail.com

ORCID ID: 0000-0002-2517-2795

\author{
Антонюк О.П. \\ кандидат экономических наук, доцент \\ кафедра учета и аудита \\ E-mail: olegantoni@ukr.net \\ ORCID ID: 0000-0002-9182-4982
}

\author{
Баранюк К.А. \\ ассистент \\ кафедра учета и аудита \\ Одесская национальная академия пищевых \\ технологий \\ ул. Канатная, 112, г. Одесса, Украина, 65039 \\ E-mail: baranyuk.kristina@gmail.com
}

ORCID ID: 0000-0002-3346-0332

\section{АНАЛИЗ СОСТОЯНИЯ ТОРГОВЛИ АГРОПРОДОВОЛЬСТВЕННЫМИ ТОВАРАМИ УКРАИНЫ И СТРАН АФРИКИ}

В статье исследуются вопросы современного состояния торговли агропродовольственной продукцией между Украиной и странами Африки. Исследование базируется на использовании системного подхода к оценке ситуаций, характерных для африканского рынка и экономико-логических методов и приёмов экономического анализа. В результате исследования установлено, что агропродовольственная продукция становится основным экспортным товаром в торговле Украины со странами этого континента, но, несмотря на это, в их продовольственном импорте доля Украины не превышает 3,0\%, то есть страна находится на начальном этапе вхождения на африканский рынок. В товарной структуре экспорта продукции сельского хозяйства и пищевой промышленности преобладает сырьё и продукция с невысокой добавленной стоимостью (зерновые, масличные, а так же нерафинированное подсолнечное масло), хотя за период 2013-2017 гг. их удельный вес в общем продовольственном экспорте сократился на 12,1 \% пункта. В тоже время абсолютно и относительно возрастает экспорт продуктов животного происхождения и готовых пищевых продуктов - мясо птицы, молочные 
продукты, сахар, шрот масличных культур, табачные изделия. Выполненный анализ свидетельствует о значительных диспропорциях в территориальной структуре африканского импорта из Украины. Основные экспортные потоки агропродовольственной продукции направляются в шесть стран Северной Африки (Алжир, Египет, Ливия, Марокко, Судан, Тунис), которые входят в десятку наибольших импортёров континента. В тоже время в другие 48 стран - Субсахарская Африка, где проживает более $80 \%$ населения континента и которые есть потенциально огромным рынком для украинского бизнеса, приходится около 18,0 \% продовольственного экспорта с Украины, что свидетельствует о значительных возможностях роста продаж в эти страны.

Установлена высокая результативность экспортно-импортных операций в торговле агропродовольственными товарами Украины и стран Африки: значительное положительное сальдо и самый высокий по сравнению со странами СНД, ЕС и Азии коэффициент покрытия экспорта импортом.

По результатам исследования предоставлены предложения по увеличению экспорта на основе увеличения товарных ресурсов страны и усиления дипломатической поддержки.

Ключевые слова: агропродовольственная продукция, экспорт, товарная структура, субрегионы, территориальная структура, сальдо, дипломатическая поддержка.

\author{
Antonyuk $\mathbf{P}$. \\ Ph.D., Researcher \\ Department of Market Mechanisms and Structures \\ Institute of Market Problems and Economic \& Ecological \\ Research of National Academy of Sciences of Ukraine \\ Frantsuzskiy boulevard, 29, Odesa, Ukraine, 65044 \\ E-mail: paul_antonyuk@ukr.net \\ ORCID ID: 0000-0002-8100-2563 \\ Stupnytska T. \\ Ph.D., Associate Professor \\ Department of Accounting and Auditing \\ E-mail: t.stupnitska@gmail.com \\ ORCID ID: 0000-0002-2517-2795
}

\author{
Antonyuk 0. \\ Ph.D., Associate Professor \\ Department of Accounting and Auditing \\ E-mail: olegantoni@ukr.net \\ ORCID ID: 0000-0002-9182-4982
}

\author{
Baraniuk Kh. \\ Assistant \\ Department of Accounting and Auditing \\ Odesa National Academy of Food Technologies \\ Kanatna str., 112, Odesa, Ukraine, 65039 \\ E-mail: baranyuk.kristina@gmail.com \\ ORCID ID: 0000-0002-3346-0332
}

\section{ANALYSIS OF THE STATE OF TRADE IN AGRICULTURAL GOODS OF UKRAINE AND AFRICAN COUNTRIES}

The article examines the current state of trade in agri-food products between Ukraine and African countries. The study is based on use of a systematic approach to assessing situations characteristic for the African market and economic and logical methods and techniques of the economic analysis. As a result of the study, it has been established that agri-food products are becoming the main export goods in Ukraine's trade with the countries of this continent, but despite this, Ukraine's share in food imports does not exceed $3.0 \%$, that is, the country is at the initial stage of entering the African market. Raw materials and products with low value added (grains, oilseeds, and unrefined sunflower oil) dominate in the commodity structure of exports of agricultural and food products, although over the period of 2013-2017. their share in total food exports fell by $12.1 \%$. At the same time, exports of animal products and finished food products: poultry meat, dairy products, sugar, oilseed meal, tobacco products, - absolutely and relatively increase. The analysis performed indicates significant disproportions in the territorial structure of African imports from Ukraine. The main export streams of agri-food products are sent to six countries in North Africa (Algeria, Egypt, Libya, Morocco, Sudan, Tunisia), which are among the ten largest importers of the continent. At the same time, the other 48 countries - Sub-Saharan Africa, where more than $80 \%$ of the continent's population lives and which is a potentially huge market for Ukrainian business, account for about $18.0 \%$ of food exports from Ukraine, which indicates significant sales growth opportunities in these countries.

The high efficiency of export-import operations in the trade of agri-food products in Ukraine and African countries was established: a significant positive balance and the highest ratio of export cover by imports compared to countries in the CIS, EU and Asia.

According to the results of the research, proposals for increasing exports based on an increase in the country's commodity resources and strengthened diplomatic support have been made.

Key words: agri-food products, exports, commodity structure, subregions, territorial structure, balance, diplomatic support. 


\section{References}

1. Antoniuk, O. P., Antoniuk, P. O., \& Lysiuk, V. M. (2018). Krainy Azii - holovnyi partner Ukrainy v torhivli ahroprodovolchym tovaramy. Food Industry Economics, 10(2), 22-30. doi:10.15673/fie.v10i2957

2. Derzhavna sluzhba statystyky Ukrainy. (2019). Retrieved April 05, 2019, from http://ukrstat.gov.ua/

3. Druzhenko, V. (2018). Boroshno: Shliakhy eksportu nezbahnenni. Propozytsiia, (1), 158-161.

4. Dukhnytskyi, B. V. (2018). Hlobalnyi popyt na prodovolstvo. Ekonomika APK, (8), 102-105.

5. Kyrylenko, I. H., Ivchenko, V. Ye., \& Demenchuk, V. V. (2018). Osnovni tendentsii rozvytku svitovoho prodovolchoho rynku ta vyrobnytstva prodovolstva v Ukraini. Ekonomika APK, (9), 34-43. doi: 10.32317/22211055.201809034

6. Lysak, M. A., \& Sheremet, O. O. (2017). Zovnishnia torhivli v umovakh intehratsii Ukrainy. Ekonomika $A P K$, (12), 69-74.

7. Maslak, O., \& Kutsenko, I. (2017). Osoblyvosti ukrainskoho eksportu. Propozytsiia, (10), 156-158.

8. Nelep, V. M. (2011). Otsinka eksportnykh mozhlyvostei ahroprodovolchoho kompleksu Ukrainy. Ekonomika Ukrainy, (9), 54-63.

9. Lupenko, Yu. O., \& Puhachov, M. I. (Eds.). (2015). Formuvannia hlobalnoho i rehionalnoho rynkiv silskohospodarskoi syrovyny. Kyiv: NNTs "IAE".

10. V novom sezone Egipet suschestvenno sokratil import ukrainskogo podsolnechnogo masla. (2018). Retrieved April 02, 2019, from https://elevatorist.com/novosti/6737-v-novom-sezone-egipet-suschestvenno-sokratilimport-ukrainskogo-podsolnechnogo-masla

11. Karta, kotoraya ob'yasnyaet raznitsu v torgovoy politike Zapada i Ukrainyi. (2018). Retrieved April 02, 2019, from https://businessviews.com.ua/ru/economy/id/karta-kotoraja-objasnjaet-raznicu-v-torgovoj-politike-zapada-iukrainy-1797/

12. Eksport do Afriki: MozhlivostI I pereshkodi // PropozitsIya golovna platforma dlya agrobIznesu. (2017). Retrieved April 02, 2019, from https://propozitsiya.com/ua/eksport-do-afriki-mozhlivosti-i-pereshkodi

13. Eksport v Afriku: V chem shansyi i riski dlya ukrainskih kompaniy. (2018). Retrieved April 02, 2019, from https://biz.liga.net/uaexport/all/article/eksport-v-afriku-v-chem-riski-i-vozmojnosti-dlya-ukrainskiy-kompan

14. Afrique subsaharienne: La facture des importations alimentaires continue de flamber. (2017). Retrieved April 02, 2019, from https://afrique.latribune.fr/finances/commodities/2017-06-11/afrique-subsaharienne-la-facture-desimportations-alimentaires-continue-de-flamber-736553.html

15. L'Egypte, L'Algérie et le Maroc sont le plus gros importateurs du ble dans le monde. (2017). Retrieved April 02, 2019, from https://maghrebemergent.info/L-Egypte-L-Algérie-et-le-Maroc-sont-le-plus-gros-importateurs-duble-dans-le-monde/

16. En 2016, le continent africain a importe des produits alimentaires pour 65.8 milliars dolars (rapport). (2017). Retrieved April 02, 2019, from https://www.agenceecofin.com/commerce/2709-50609.-en2016-le-continentafricain-a-importe-des-produits-alimentaires-pour-65.8-milliars-dolars-rapport

17. En 2017, L`Algerie sepositione sur le marché africain de sucre. (2017). Retrieved April 02, 2019, from https://www.commodafric.com/08-01-2018-en-2017-lalgerie-sepositione-sur-le- marché-africain-de-sucre

18. La situation des marches des produits agricoles. Commerce et securite alimentaire trouver en meilleur equlibre entre les priorites nationale et le lien common. (2015). Retrieved April 05, 2019, from http://www.fao.org/3/ai5090f.pdf

19. Importations alimentaires: L'Afrique attendra 110 milliards dollars d'ici a 2030 jans une alternative credible. (2017). Retrieved April 02, 2019, from http://www.adiac.-congo.com/content/importations-alimentaires-L'Afriqueattendra-110-milliards-dollars-d'ici-a-2030-jans-une-alternative-credible

20. Les produits les plus importés par l'Afrique. (2017). Retrieved April 02, 2019, from https://www.waystocap.com/blog/?s=Les produits les plus importés par l'Afrique

Received 14 April 2019

Approved 24 April 2019

Available in Internet 5.07.2019

Цитування згідно ДСТУ 8302:2015

Антонюк П.О., Антонюк О.П., Ступницька Т.М., Баранюк Х.О. Аналіз стану торгівлі агропродовольчими товарами України з країнами Африки // Економіка харчової промисловості. 2019. Т.11, вип. 2. С. 3-12. doi: 10.15673/fie.v11i2.1388

Cite as APA style citation

Antonyuk P., Antonyuk O., Stupnytska T. \& Baraniuk Kh. (2019). Analysis of the state of trade in agricultural goods of Ukraine and African countries. Food Industry Economics, 11(2), 3-12. doi: 10.15673/fie.v11i2.1388 